\title{
Evaluation of Hot Pepper (Capsicum annuum L.) Genotypes for Yield and Quality in Ethiopia
}

\author{
Melkamu Hinsermu ${ }^{1}$, Yosef Alemu ${ }^{1}$, Shimelis Aklilu ${ }^{1}$, Haile Abebe ${ }^{2}$, Jibicho Geleto ${ }^{1}$,Tesfa Binalfew ${ }^{1}$, \\ Gebeyehu Wondimu', Selamawit Ketema ${ }^{1}$, Dessie Getahun ${ }^{3}$ \\ 1. Melkassa Agricultural Research Center, Melkassa, Ethiopia \\ 2. Mehoni Agricultural Research Center, Mehoni, Ethiopia \\ 3. Fogera Agricultural Research Center, Fogera, Ethiopia \\ Email of Corresponding Author: melkamuhinsermu12@gmail.com
}

\begin{abstract}
Hot pepper (Capsicum annum L) is the dominant vegetable crop grown in different parts of Ethiopia playing an important role for nutrition, income generation and foreign currency earnings. The production of the crop, however, is constrained by pre- and post-harvest-pests and limited improved varieties with important traits such as disease resistance.Therefore, a field experiment was conducted at Melkassa and Mehoni agricultural research centers during the main and off-seasons in 2017 and 2018 to develop hot pepper varieties with high green and/dry pod yield and acceptable pod quality. The experiment comprised of seven hot pepper genotypes (PBC731, ICPN-9\#16, PBC-602, Rivival, PGRC-80021, Melka Awaze, and Marko Fana) laid out in Randomized Complete Block Design with three replications. They were evaluated for yield and physical pod characterstics at two different locations. The overall combined total green pod yield across locations/season and years showed non-significant difference among genotypes, but genotypes ICPN $9 \# 16$ (262 q/ha), Rivival (249 q/ha), and PBC $602(208 \mathrm{q} / \mathrm{ha})$ gave higher total green pod yield than standard check varieties in that order. Similarly, though there was no significant difference among genotypes for the combined analysis of variance for total dry pod, PBC 602 (30.8 q/ha), Rivival (29.4 q/ha) and ICPN 9\#16 (29.3 q/ha) gave higher yield compared to the check varieties. The per location and combined analysis of variance showed significant $(\mathrm{P}<0.01)$ differences in marketable and total green and dry pod yields at Melkassa and Mehoni during the rainfed seasons, but only at Melkassa under irrigation condition. Significant differences were also observed among the genotypes in plant height, pod number per plant, pod length, and pod wall thickness. Moreover, PBC-602 had elongate pod shape, green pod color, smooth pod surface, and highly pungent which are the preference of consumers in green pod markets. Similarly, Rivival had elongate pod shape, dark green pod color, brown dry pod color, smooth pod surface and medium pungency which could be used for both dry pod and green pod markets. Consequently, Rivival named as Gebaba (for green and dry pod), and PBC-602 named as Chala (for green pod) purposes were released for production in agro-ecologies of Ethiopia similar to that of Melkassa and Mehoni. The released varieties thus should be promoted for production under wider areas recommended for hot pepper.
\end{abstract}

Keywords: genotypes, wall thickness, pungency

DOI: $10.7176 /$ ALST/92-01

Publication date: February $28^{\text {th }} 2022$

\section{Introduction}

Hot pepper (Capsicum annuum L.) is one of the vegetable crops that belong to the Solanaceae family (Kumar et al., 2011). It is the second most economically important vegetable crop of the family after tomato in the world (Rubatzky and Yamaguchi, 1997; Berhanu et al., 2011). It is the most important for pungency and oleoresin extraction that attributes in food products, as a spice, and in pharmaceutical applications. It is a used as spice for flavoring and coloring of foods, providing essential vitamins and minerals (Bosland and Votava, 2012).

The world total area coverage of hot pepper for dry and green is estimated to be 1,989,664 and 1,914,685 hectares in 2012 with a total production of 3,352,163 and 31,171,567 tones, respectively. While in Ethiopia total area coverage for the dry and green hot pepper, respectively is 172,142.2 and 10,473.07 hectares in 2018/19 with a total production of 307,457.1 and 62,247.5 tones, respectively (CSA, 2018/19). The top five leading hot pepper producing countries in the world are India, China, Peru, Bangladesh, and Pakistan. In Ethiopia, central (Eastern and Southern Shoa), western, north-western (Wellega, Gojjam), and the northern parts of the country are the potential hot pepper producing areas in the country (Girma et al., 2001).

The national average productivity of the crop is $0.286 \mathrm{t} / \mathrm{ha}$ for dry pepper and $2.734 \mathrm{t} / \mathrm{ha}$ for green pod far below the world average productivity; $1.685 \mathrm{t} / \mathrm{ha}$ for dry pod and $16.28 \mathrm{t} /$ ha for green pod (FAOSTAT, 2012). The major production constrains attributed to the low productivity of the crop in the country among others include pre and post harvest pests, , limited improved varieties (disease resistant) and quality seed of released varieties (Vicente et al., 2007 and Topuz and Ozdemir, 2007).

In order to solve these problems, the National Warm Season Vegetable Research Program considered hot papper as high priority crop in the research program and has been focusing on its breeding. In the course of 
improvement activities germplasm have been collected from major producing areas, acquired the Ethiopian Institute of Biodiversity (EIB) and introduced from World Vegetable Center, the Asian Vegetable Research and Development Center (AVRDC, Taiwan). Thus the present study was conducted to evaluate and identify hot pepper vareties with high green/dry pod yield and quality for wider production and consumption in the country.

\section{Material and Methods}

Five hot pepper genotypes (PBC-731, ICPN-9\#16, PBC-602, Rivival, and PGRC-80021) introduced from World Vegetable Center, the Asian Vegetable Research and Development Center (AVRDC, Taiwan) were evaluated along with two locally released standard check varieties (Melka Awaze and Marko Fana). The genotypes were evaluated in 2017 and 2018 cropping season at Melkassa and Mehoni agricultural research centers. Melkassa Agricltural Researtch Center (MARC) is located in the Central Rift Valley of Ethiopia at $8^{\circ} 24^{\prime} \mathrm{N}$ latitude, $39^{\circ} 21^{\prime} \mathrm{E}$ longitude, and altitude of 1,550 m.a.s.l. The average annual rainfall is $768 \mathrm{~mm}$ and the mean maximum and minimum temperatures are $28.5^{\circ} \mathrm{C}$ and $12.6^{\circ} \mathrm{C}$ respectively. Mehoni Agricultural Research center (MeARC) in the Raya Valley, Northern Ethiopia at $12^{\circ} 41^{\prime} 50 \mathrm{~N}^{\prime}$ Latitude and $39^{\circ} 42^{\prime} 08 \mathrm{E}^{\prime}$ Longitude with an altitude of 1578 m.a.s.l. The site receives a mean annual rainfall of $300 \mathrm{~mm}$ with an average minimum and maximum temperature of 22 and $32^{\circ} \mathrm{C}$, respectively. The soil textural class of the experimental area is clay loam with pH of 7.9-8.1(MeARC, 2015). The field trials in both years were conducted in the rainy season with supplementary irrigation and in the dry season using full irrigation. The experiment was laid out in Randomized Complete Block Design with three replications in a plot size of $8.4 \mathrm{~m}^{2}$ having four rows with the spacing of $70 \mathrm{~cm}$ and 30 $\mathrm{cm}$ between rows and plants, respectively. Fertilizers, NPS (242 kg/ha) was applied just before transplanting, while urea $(79 \mathrm{~kg} / \mathrm{ha})$ was applied in two splits, $50 \%$ two weeks after transplanting and the remaining $50 \%$ one and half month after transplanting. Fungicides Ridomil gold and Bylaton were applied at the rate of $(3.5 \mathrm{~kg} / \mathrm{ha})$ to control the different leaf diseases; bacterial leaf spot and powdery mildew, respectivly and Karate 5\% (2.5 1/ha) was also applied against insect pests (African boll worm and aphids). Other necessary cultural practices were applied to all plots uniformly as needed. Data were collected from the central two rows. Data on days to $50 \%$ flowering, plant height, growth habit, green and dry marketable and total yields, pod characters (pod length, pod diameter, pod number per plant, pod wall thickness, pod color, pod shape, pod surface and pungency) were collected. Quantitative data were subjected to environment wise analysis of variance followed by pooled analysis of variance. GENES software package was used to compute the pooled ANOVA, while statistix 10 was used for mean separation (Cruz, 2013).

\section{Result and Discussions}

\section{Marketable and Total Green Pod Yield}

The combined analysis of variance for marketable and total green pod yield of hot pepper genotypes were highly significant $(P<0.01)$ under rainfed condition (Tables 1 and 2) at both locations. It ranged from 153.6 to $257 \mathrm{q} / \mathrm{ha}$ and 161 to $270.2 \mathrm{q} /$ ha for marketable and total green pod yields, respectively. ICPN- 9\#16 (257.2 q/ha), Rivival (226.3 q/aha) and PBC 602 (201.4 q/ha) were the top yielder for green marketable yield. Similar trend was observed for total green pod yield. The individual location analysis of variance during this season showed a significant difference among genotypes at Mehonni, but at Melkassa for marketable yield while it was significant at both locations for the total yield. Rivival (317.5 q/ha), PGRC 80021 (269 q/ha), ICPN 9\#16 (268.6 q/ha), PBC 602 (23.02 q/ha), and are the top yielder during 2017 rainfed at Mehonni, while Rivival (179.9 q/ha), ICPN 9\#16 (145 q/ha), PBC 731 (143 q/ha) and PBC 602 (101.4 q/ha) at mehonni in 2018 and ICPN 9\#16 (357.2 q/ha), PBC 602 (300.4 q/ha) and Rivival (229.1 q/ha) were the highest at Melkassa in 2017.

The combined analysis of variance across years/locations under irrigated condition showed non-significant difference among genotypes for marketable and total yield. The variability among genotypes, however, ranged from $272.7 \mathrm{q} /$ ha for variety Mareko fana to $250 \mathrm{q} /$ ha for ICPN 9\#16. Similarly, the total yield ranged from 170.3 $\mathrm{q} /$ ha to $262 \mathrm{q} / \mathrm{ha}$ for the same genotypes. The individual location/years analysis of variance for marketable yield in this season showed significant difference at Melkassa. ICPN 9\#16 (250 q/ha), Rivival (226.3 q/ha), and PBC731 (178.9 q/ha) were the top yielder. Similar trend was observed for the total yield; significant at Melkassa, but at Mehonni. ICPN 9\#16, Rivival and PBC 602 were the highest yielder.

The overall analysis of variance across seasons, location and years showed non-significant difference among genotypes for marketable and total yield. However, ICPN 9\#16, PBC 602 and Rivival gave higher marketable and total green pod yield than the standard check varieties (table 1 and 2). 
Table 1. Marketable green pod yield (q/ha) at Melkassa and Mehoni in 2017 and 2018 under rainfed and irrigated conditions

\begin{tabular}{|c|c|c|c|c|c|c|c|c|}
\hline \multirow{2}{*}{ Genotypes } & \multicolumn{2}{|c|}{$2017^{*}$} & $2018^{*}$ & \multirow{2}{*}{ Combined } & \multicolumn{2}{|l|}{$2017 * *$} & \multirow{2}{*}{$\begin{array}{c}\text { Combine } \\
\mathrm{d}\end{array}$} & \multirow{2}{*}{$\begin{array}{l}\text { Over } \\
\text { all }\end{array}$} \\
\hline & Melkassa & Mehoni & Mehoni & & Mehoni & Melkassa & & \\
\hline PBC-731 & 232.4 & $213.0^{\mathrm{c}}$ & $143.0^{\mathrm{abc}}$ & $196.4^{\mathrm{bc}}$ & 196.5 & $178.9^{\mathrm{bc}}$ & 187.7 & 190.0 \\
\hline ICPN-9\#16 & 357.2 & $268.6^{\mathrm{b}}$ & $145.2^{\mathrm{ab}}$ & $257.0^{\mathrm{a}}$ & - & $250.0^{\mathrm{a}}$ & 250.0 & 249.9 \\
\hline PBC-602 & 300.4 & $230.2^{b c}$ & $101.4^{\text {cde }}$ & $201.4^{\mathrm{bc}}$ & 251.9 & $159.3^{c}$ & 205.6 & 219.9 \\
\hline Rivival & 229.1 & $317.5^{\mathrm{a}}$ & $179.9^{\mathrm{a}}$ & $226.3^{\mathrm{ab}}$ & 274.9 & $226.6^{\mathrm{ab}}$ & 250.7 & 245.6 \\
\hline PGRC-80021 & 212.1 & $269.8^{\mathrm{b}}$ & $68.9^{\mathrm{e}}$ & $199.5^{\mathrm{bc}}$ & 237.7 & $89.5^{\mathrm{de}}$ & 163.6 & 175.6 \\
\hline Melka Awaze & 244.9 & $204.3^{\mathrm{c}}$ & $94.1^{\mathrm{de}}$ & $181.0^{\mathrm{bc}}$ & 241.3 & $130.3^{\mathrm{cd}}$ & 185.8 & 182.9 \\
\hline Marko Fana & 131.7 & $208.1^{\mathrm{c}}$ & $120.9^{\mathrm{bcd}}$ & $153.6^{c}$ & 293.8 & $51.8^{\mathrm{e}}$ & 293.8 & 172.7 \\
\hline F-test & $\mathrm{NS}$ & $* *$ & $* *$ & $* *$ & $\mathrm{NS}$ & $* *$ & $\mathrm{NS}$ & $\mathrm{NS}$ \\
\hline Mean & 244.1 & 244.6 & 121.9 & 202.2 & 249.4 & 155.2 & 219.6 & 205.3 \\
\hline $\mathrm{CV}$ & 3.0 & 6.7 & 19.2 & 25.0 & 33.2 & 21.1 & 26.0 & 25.2 \\
\hline
\end{tabular}

Means followed by the same letter are not significantly different at $p<0.05$ and 0.01

Note: * Rainfed; ** Irrigated

Table 2. Total green pod yield (q/ha) at Melkassa and Mehonni in 2017 and 2018 under rainfed and irrigated conditions

\begin{tabular}{|c|c|c|c|c|c|c|c|c|}
\hline \multirow{2}{*}{ Genotypes } & \multicolumn{2}{|c|}{$2017 *$} & $2018^{*}$ & \multirow{2}{*}{ Combined } & $2017 * *$ & $2018 * *$ & \multirow{2}{*}{$\begin{array}{c}\text { Combin } \\
\text { ed }\end{array}$} & \multirow{2}{*}{$\begin{array}{l}\text { Over } \\
\text { all }\end{array}$} \\
\hline & Melkassa & Mehoni & Mehoni & & Mehoni & Melkassa & & \\
\hline PBC-731 & 233.2 & $217.0^{c}$ & $158.0^{\mathrm{b}}$ & $203.0^{\mathrm{bc}}$ & 203.2 & $180.5^{\mathrm{bc}}$ & 191.8 & 197.4 \\
\hline ICPN-9\#16 & 259.8 & $278.0^{\mathrm{c}}$ & $172.3^{\mathrm{ab}}$ & $270.2^{\mathrm{a}}$ & - & $253.7^{\mathrm{a}}$ & 253.7 & 262.0 \\
\hline PBC-602 & 302.2 & $233.0^{\mathrm{bc}}$ & $107.7^{\mathrm{cd}}$ & $204.9^{b c}$ & 260.2 & $161.1^{\mathrm{c}}$ & 210.6 & 207.8 \\
\hline Rivival & 212.5 & $325.3^{\mathrm{a}}$ & $203.6^{\mathrm{a}}$ & $236.0^{\mathrm{ab}}$ & 283.0 & $228.2^{\mathrm{ab}}$ & 255.6 & 245.8 \\
\hline PGRC-80021 & 230 & $274.5^{\mathrm{b}}$ & $83.2^{\mathrm{d}}$ & $207.0^{\mathrm{ab}}$ & 251.3 & $90.7^{\mathrm{cd}}$ & 171. & 189.0 \\
\hline Melka Awaze & 245.8 & $209.3^{c}$ & $108.9^{\mathrm{cd}}$ & $188.0^{\mathrm{bc}}$ & 249.3 & $134.2^{\mathrm{cd}}$ & 191. & 189.9 \\
\hline Marko Fana & 132.4 & $213.9^{c}$ & $136.1^{\mathrm{bc}}$ & $161.0^{\mathrm{c}}$ & 305.3 & $53.8^{\mathrm{e}}$ & 179.5 & 170.3 \\
\hline Mean & 245.1 & 250.3 & 138.5 & 210.0 & 258.7 & 157.5 & 207.7 & 209 \\
\hline F-test & NS & $* *$ & $* *$ & $* *$ & NS & $* *$ & NS & NS \\
\hline $\mathrm{CV}$ & 29.8 & 6.41 & 18.5 & 24.3 & 32.3 & 21.0 & 26.5 & 25.4 \\
\hline
\end{tabular}

Means followed by the same letter are not significantly different at $p<0.05$ and 0.01

Note: * Rainfed; ** Irrigated

\section{Marketable and Total Dry Pod Yield}

The combined analysis of variance for marketable and total dry pod yield of hot pepper genotypes were highly significant $(P<0.01)$ under rainfed condition (Tables 3 and 4$)$ at both locations. It ranged from 18.2 to $30.2 \mathrm{q} / \mathrm{ha}$ and 20.4 to $32.7 \mathrm{q} /$ ha for marketable and total dry pod yields, respectively. PBC (30.2 q/ha), Melka awaze (29.3 $\mathrm{q} / \mathrm{ha}$ ) and Rivival (25.6 q/ha) and were the top yielder for dry marketable yield. Similar trend was observed for total dry pod yield.

The individual location analysis of variance during this season showed a significant difference among genotypes at both Melkassa and Mehonni for marketable and total dry pod yield. PBC 602 (34.9 q/ha and 39.7 q/ha), Melka awaze (34.6 q/ha and $35.7 \mathrm{q} / \mathrm{ha}$ ) and Rivival (33.3 q/ha and 35.5 q/ha ) are top for marketable and total dry pod yield at Melkassa during 2017 under rain fed. While at Mehoni genotype PGRC- 80021(39.5 q/ha and $42.6 \mathrm{q} / \mathrm{ha})$, PBC-602 (36.6 q/ha and $38.3 \mathrm{q} / \mathrm{ha}$ ) and Markofana (35.8 q/ha and $38.9 \mathrm{q} / \mathrm{ha}$ ) are top yielder for marketable and total dry pod yield at Mehoni during 2017 under rainfed condtions. In 2018 genotypes Rivival followed by Melka awaze standard check are higher yield for marketable and total dry pod yield at Mehoni under rainfed.

The combined analysis of variance across years/locations under irrigated condition showed non-significant difference among genotypes for marketable and total dry pod yield. It ranged from 17.3 to $30.2 \mathrm{q} /$ ha and 23 to 33 $\mathrm{q} /$ ha for marketable and total dry pod yield, respectively. The individual location/years analysis of variance for marketable dry pod yield in this season showed significant difference at Melkassa, but not at Mehoni. ICPN 9\#16 (30.2 q/ha), PBC-602 (24.6 q/ha) and PBC-731 (23.5 q/ha) were the top yielder. Similar trend was observed for the total yield; significant at Melkassa during 2018.

The overall analysis of variance across seasons, location and years showed non-significant difference 
among genotypes for marketable and total dry pod yield. However, genotype PBC-602 (27.6 and 30.85 q/ha) gave the higher marketable and total dry pods yield, respectively followed Melka Awaze (check) and Rivival (table 3 and 4).

Table 3. Marketable dry pod yield (q/ha) at Melkassa and Mehoni in 2017 and 2018 under rainfed and irrigated conditions

\begin{tabular}{|c|c|c|c|c|c|c|c|c|}
\hline \multirow{2}{*}{ Genotypes } & \multicolumn{2}{|c|}{$2017 *$} & \multirow{2}{*}{$\begin{array}{l}2018 * \\
\text { Mehoni }\end{array}$} & \multirow{2}{*}{ Combined } & $2017 * *$ & $2018 * *$ & \multirow{2}{*}{ Combined } & \multirow{2}{*}{$\begin{array}{l}\text { Over } \\
\text { All }\end{array}$} \\
\hline & Melkassa & Mehoni & & & Mehoni & Melkassa & & \\
\hline PBC- 731 & $18.4^{\mathrm{bc}}$ & $29.6^{\mathrm{bc}}$ & $17.8^{\mathrm{ab}}$ & $21.9^{\mathrm{bc}}$ & 31.5 & $23.5^{\mathrm{ab}}$ & 27.5 & 24.7 \\
\hline ICPN-9\#16 & $27.9^{\mathrm{ab}}$ & $23.0^{\mathrm{c}}$ & $17.0^{\mathrm{ab}}$ & $22.6^{\mathrm{bc}}$ & - & $30.2^{\mathrm{a}}$ & 30.2 & 26.4 \\
\hline PBC-602 & $34.9^{\mathrm{a}}$ & $36.6^{\mathrm{ab}}$ & $19.0^{\mathrm{ab}}$ & $30.2^{\mathrm{a}}$ & 25.6 & $24.6^{\mathrm{ab}}$ & 25.1 & 27.6 \\
\hline Rivival & $33.3^{\mathrm{a}}$ & $25.8^{\mathrm{c}}$ & $22.6^{\mathrm{a}}$ & $25.6^{\mathrm{ab}}$ & 28.0 & $23.2^{\mathrm{ab}}$ & 25.6 & 25.6 \\
\hline PGRC-80021 & $27.2^{\mathrm{ab}}$ & $39.5^{\mathrm{a}}$ & $4.0^{c}$ & $25.2^{\mathrm{ab}}$ & 21.2 & $13.5^{\mathrm{bc}}$ & 17.3 & 21.3 \\
\hline Melka Awaze & $34.6^{\mathrm{a}}$ & $34.0^{\mathrm{ab}}$ & $19.2^{\mathrm{a}}$ & $29.3^{\mathrm{a}}$ & 32.9 & $13.5^{\mathrm{bc}}$ & 23.2 & 26.2 \\
\hline Marko Fana & $9.0^{\mathrm{c}}$ & $35.8^{\mathrm{ab}}$ & $10.0^{\mathrm{bc}}$ & $18.2^{\mathrm{c}}$ & 28.2 & $8.3^{c}$ & 18.25 & 18.2 \\
\hline Mean & 26.5 & 32.0 & 15.6 & 24.7 & 27.9 & 19.5 & 23.7 & 24.2 \\
\hline F-test & $* *$ & $* *$ & $* *$ & $* *$ & NS & $* *$ & NS & NS \\
\hline $\mathrm{CV}$ & 26.5 & 13.0 & 32.9 & 24.8 & 20.1 & 32.5 & 26.2 & 25.5 \\
\hline
\end{tabular}

Means followed by the same letter are not significantly different at $p<0.05$ and 0.01

Note: * Rainfed; ** Irrigated

Table 4. Total dry pod yield (q/ha) at Melkassa and Mehoni in 2017 and 2018 under rainfed and irrigated conditions

\begin{tabular}{|c|c|c|c|c|c|c|c|c|}
\hline \multirow{2}{*}{ Genotypes } & \multicolumn{2}{|c|}{$2017^{*}$} & \multirow{2}{*}{$\begin{array}{r}2018 * \\
\text { Mehoni }\end{array}$} & \multirow{2}{*}{ Combined } & $2017 * *$ & $2018 * *$ & \multirow{2}{*}{ Combined } & \multirow{2}{*}{$\begin{array}{l}\text { Over } \\
\text { all }\end{array}$} \\
\hline & Melkassa & Mehoni & & & Mehoni & Melkassa & & \\
\hline PBC- 731 & $19.9^{\mathrm{bc}}$ & $32.0^{\mathrm{bcd}}$ & $19.0^{\mathrm{ab}}$ & $23.9^{\mathrm{bc}}$ & 41.4 & $25^{\mathrm{ab}}$ & 33 & 28.45 \\
\hline ICPN-9\#16 & $29.8^{\mathrm{ab}}$ & $26.5^{d}$ & $23.4 \mathrm{a}$ & $26.6^{\mathrm{abc}}$ & - & $32^{\mathrm{a}}$ & 32 & 29.3 \\
\hline PBC-602 & $39.7^{\mathrm{a}}$ & $38.3^{\mathrm{ab}}$ & $20.1^{\mathrm{ab}}$ & $32.7^{\mathrm{a}}$ & 32.3 & $25^{\mathrm{ab}}$ & 29 & 30.85 \\
\hline Rivival & $35.5^{\mathrm{a}}$ & $28.0^{\mathrm{cd}}$ & $25.8^{\mathrm{a}}$ & $27.8^{\mathrm{ab}}$ & 38.3 & $23.7^{\mathrm{ab}}$ & 31 & 29.4 \\
\hline PGRC-80021 & $28.6^{\mathrm{ab}}$ & $42.6^{\mathrm{a}}$ & $5.2^{\mathrm{c}}$ & $27.5^{\mathrm{ab}}$ & 32.3 & $14.2^{\mathrm{bc}}$ & 23 & 25.25 \\
\hline Melka Awaze & $35.7^{\mathrm{a}}$ & $38.9^{\mathrm{ab}}$ & $22.1^{\mathrm{ab}}$ & $31.3^{\mathrm{a}}$ & 41.7 & $16.4^{\mathrm{bc}}$ & 29 & 30.15 \\
\hline Marko Fana & $10.5^{\mathrm{c}}$ & $38.9^{\mathrm{ab}}$ & $11.9^{\mathrm{bc}}$ & $20.4^{\mathrm{c}}$ & 42.6 & $8.9^{c}$ & 26 & 23.2 \\
\hline Mean & 28.6 & 34.7 & 15.63 & 27.2 & 38 & 20.8 & 29.0 & 28.1 \\
\hline F-test & $* *$ & $* *$ & $* *$ & $* *$ & NS & $*$ & NS & NS \\
\hline $\mathrm{CV}$ & 27.8 & 13.4 & 32.4 & 25.2 & 16.6 & 34.7 & 25.6 & 25.4 \\
\hline
\end{tabular}

Means followed by the same letter are not significantly different at $p<0.05$ and 0.01

Note: * Rainfed; ** Irrigated

\section{Vegetative and Pod Characteristics}

There was significant difference $(\mathrm{P}<0.01)$ among genotypes interms of plant height, pod number per plant, and pod length. Non-significant difference $(\mathrm{P}<0.05)$ was observed for days to $50 \%$ flowering, pod diameter and pod wall thickness (table 5). The tallest plant height was recorded for Melka awaze $(80.7 \mathrm{~cm})$ standard check, while the Rivival $(60.7 \mathrm{~cm})$, Marko Fana $(61.2 \mathrm{~cm})$ and PBC-602 $(61.7 \mathrm{~cm})$ were short. The highest number of pods per plant was found in genotype PBC-602 (174), while the lowest was recorded in Marko Fana (60). The longest pod was found in genotype PBC-602 (116.5 mm), while shorter podes were recorded in Marko Fana $(87.3 \mathrm{~mm})$, PBC-731 (88 mm), Rivival (88.3 mm) and PGRC-80021 (91 mm) (Table 5). In line with this, Delelegn et al. (2014) reported highly significant differenes in number of pods per plant, pod length and marketable yield among nine varieties evaluated in Jimma and Seka chekorsa areas of Ethiopia. 
Table 5. Vegetative and pod characteristics of hot pepper genotypes at Melkassa, 2017

\begin{tabular}{|c|c|c|c|c|c|c|}
\hline Genotypes & DF & $\mathrm{PH}$ & PNP & PL & PD & PWT \\
\hline PBC-731 & 45 & $71.0^{\mathrm{b}}$ & $76.6^{\mathrm{bc}}$ & $88.0^{\mathrm{b}}$ & 18 & 2.1 \\
\hline ICPN-9\#16 & 41 & $66.0^{\mathrm{c}}$ & $100.1^{b c}$ & $100.3^{\mathrm{ab}}$ & 19.7 & 1.5 \\
\hline PBC-602 & 46 & $61.7^{d}$ & $174.3^{\mathrm{a}}$ & $116.5^{\mathrm{a}}$ & 18.7 & 2.0 \\
\hline PGRC-80021 & 43 & $70.7^{\mathrm{b}}$ & $114.5^{\mathrm{b}}$ & $91.0^{\mathrm{b}}$ & 15.7 & 1.8 \\
\hline Rivival & 40 & $60.7^{\mathrm{d}}$ & $67.4^{\mathrm{c}}$ & $88.3^{\mathrm{b}}$ & 20 & 2.4 \\
\hline Melka Awaze & 42 & $80.7^{\mathrm{a}}$ & $87.5^{\mathrm{bc}}$ & $99.0^{\mathrm{ab}}$ & 17.7 & 1.8 \\
\hline Marko Fana & 41 & $61.2^{\mathrm{d}}$ & $60.1^{\mathrm{c}}$ & $87.3^{\mathrm{b}}$ & 21 & 2.2 \\
\hline Mean & 42.6 & 69.7 & 97.2 & 95.8 & 18.6 & 2 \\
\hline F-test & NS & $* *$ & $* *$ & $* *$ & NS & NS \\
\hline CV & 1.91 & 1.55 & 16.89 & 7.14 & 22.62 & 15.01 \\
\hline
\end{tabular}

Means followed by the same letter are not significantly different at $p<0.05$ and 0.01

*DF: Days to 50\% flowering, PH: Plant height (cm), PNP: Pod number per plant, PL: Pod length (mm), PD: Pod diameter (mm), PWT: Pod wall thickness (mm)

\section{Qualitative vegetative and pod characteristics}

PBC-602 had elongate pod shape, green pod color, smooth pod surface, and highly pungent which are the preference of consumers in green pod markets. This variety is also tolerant to soil borne diseases compared to the standard check varieties. Rivival, on the other hand, had elongate pod shape, dark green pod color, brown dry pod color, smooth pod surface and medium pungency. This variety has pod characters preferred in both dry pod and green pod markets (table 6).

Table 6. Qualitative vegetative and pod characteristics of hot pepper genotypes at Melkassa, 2017

\begin{tabular}{lllllll}
\hline Genotypes & Pod shape & GPC & DPC & Pod surface & Growth habit & Pungency \\
\hline PBC-731 & Elongate & Deep green & Brown & Smooth & Intermediate & Medium \\
ICPN9\#16 & Elongate & Light green & Light red & Semi wrinkled & Dense & Low \\
PBC-602 & Elongate & Green & Red & Smooth & Intermediate & High \\
PGRC-80021 & Elongate & Light green & Light red & Semi wrinkled & Intermediate & Low \\
Rivival & Elongate & Deep green & Brown & Smooth & Intermediate & Medium \\
Melka Awaze & Elongate & Green & Red & Smooth & Dense & Medium \\
Marko Fana & Elongate & Green & Brown & Semi wrinkled & Intermediate & High \\
\hline
\end{tabular}

*GPC: Green pod color, DPC: Dry pod color

\section{Conclusion and Recommendations}

Hot pepper (Capsicum annum L) is the dominant vegetable crops grown in different parts of Ethiopia playing an important role for nutrition, income generation and foreign currency earnings. The production of the crop, however, is constrained by pre- and post-harvest-pests and limited improved varieties with important traits such as disease resistance. Inorder to mitigate these problems, to develop hot pepper varieties that are tolerant to diseases and pests, and have high quality and yield in the mean time. In the present study seven hot pepper genotypes were evaluated under different evvironments. The overall combined total green and dry pod yield across locations/season and years showed non-significant difference among genotypes, but ICPN $9 \# 16$ (262 q/ha), Rivival (249 q/ha), and PBC 602 (208 q/ha) genotypes gave higher total green pod yield in that order, while PBC-602 (30.5 q/ha), Melka awaze (30.1 q/ha) and PBC-731 (28.4 q/ha) were top yielder for total dry pod yield. Moreover, PBC-602 had green pod color and highly pungent which are the preference of consumers in green pod markets. This variety is also tolerant to soil borne diseases compared to the standard check varieties. Similarly, Rivival had dark green pod color, brown dry pod color and medium pungency which could be used both for dry pod and green pod markets. As a result two hot pepper genotypes: Rivivial (for dual purpose) and PBC-602 (for green pod) were released for production in mid-to lowland areas of Ethiopia by National Variety Release Committee (NVRC) in 2020. Therefore, extending these varieties to a wider community of producers should follow inorder improve the productivity and production of hot pepper and benefit stackholders along its value chain.

\section{Acknowledgements}

The Authors would like to thank the Ethiopian Institute of Agricultural Research (EIAR), Melkassa Agricultural Researcher Center (MARC) for financing and provision of resources. The Authors also extend their acknowledgement for the collaborating Agricultural Research Centers (Mehoni and Fogera) for their effective implementation of the trials. 


\section{References}

Berhanu Yadeta, Derbew Belew, Wosene Gebresillase, and Fekadu Marame. 2011. Variability, heritability and genetic advance in hot pepper (Capsicum annuum L.) genotypes in west Shoa, Ethiopia. AmericanEurasian Journal of Agriculture and Environmental Science, 10(4), 587-592.

Bosland PW. and Votava EJ. 2012. Peppers, Vegetables and Spices Capsicum. CABI Publishing. New York. 22 , 198.

Cruz. C.D. 2013. GENES - a software package for analysis in experimental statistics and quantitative genetics. Acta Scientiarum. Agronomy Maringá, v. 35, n. 3, p. 271-276.

CSA (Central Statistical Agency). 2018/19. Report on Area and Production of Major Crops: The Federal Democratic Republic Of Ethiopia, Volume I.

Delelegn S., Belew D., Mohammed A. and Getachew Y. 2014. Evaluation of elite hot pepper varieties (Capsicum Sp.) for growth, dry pod yield and quality under Jimma Condition, South West Ethiopia. International Journal of Agricultural Research 9(7):364-374.

Girma T., Lidet S., Damtrew M. and Daniel B. 2001. Berebere production in Ethiopia. Ethiopian Agricultural Research Organization. Extension Material 5:03-04.

Kumar R., Dwidevi N., Singh R.K., Kumar S., Rai V.P. and Singh M. 2011. A review on molecular characterization on pepper for capsaicin and oleoresin. Intl. J. Plant. Breeding. Genet., 5: 99-110.

Rubatzky V. and Yamguchi M. 1997. World Vegetables, 2ndEdition. International Thomson Publishing, USA. 562pp. Obidiebube EA, Eruotor PG, Akparobi SO, Emosaariue SO, Achebe UA, Kator PE. 012. Response of four cultivars of pepper (Capsicum frutescens L.) to different levels of $\mathrm{N}, \mathrm{P}$ and $\mathrm{K}$ fertilizer in rainforest Agro-ecological zone. Int. J. Agric. Sci. 2(12):1143-1150.

Topuz A. and Ozdemir F. 2007. Assessment of carotenoids, capsaicinoids and ascorbic acid composition of some selected pepper cultivars (Capsicum annuum L.) grown in Turkey; Journal of Food Composition and Analysis 20:596-602.

Vicente J.L., Lopez C., Avila E., Morales E., Hargis B.M. and Tellez, G. 2007. Effect of Dietary Natural Capsaicin on Experimental Salmonella enteritidis Infection and Yolk Pigmentation in Laying Hens. International Journal of Poultry Science, 6 (6):393-396. 